\title{
Spousal Violence and Unwanted Fertility in Malawi
}

\author{
Ayotunde Titilayo ${ }^{1, a, b}$ and Martin E. Palamuleni ${ }^{\mathrm{a}}$ \\ aPopulation Training and Research Unit, North West University, Mmabatho, \\ South Africa
}

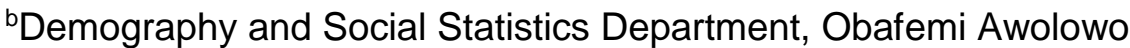 \\ University, Ile-Ife, Nigeria
}

\begin{abstract}
Identifying predictors of high fertility in Malawi has been of great concern among stakeholders. One area that has not received much attention is the relationship between spousal violence and unwanted fertility. Therefore, the objective of this paper is to establish the relationship between spousal violence (aggregate of physical, emotional and sexual) and unwanted fertility among women in Malawi. A subset of 4,137women who were selected for domestic violence module and who gave birth within the last five years were extracted from the 2010 Malawi Demographic and Health Survey. Bivariate and multivariate logistic regression analyses were used to examine the relationship between unwanted fertility and background variables. The overall prevalence rate of spousal violence and unwanted fertility among the study population are $31 \%$ and $46 \%$ respectively. Spousal violence was found to be a significant predictor of unwanted fertility among women in Malawi. The results of bivariate and multivariate logistic regression models indicate that unwanted fertility is higher among women who experienced spousal violence than among those who did not $(O R=0.765)$. Other factors that were found to be significantly related to unwanted fertility are age at first birth, number of children ever born, spousal agreement on ideal number of children household wealth index and region of residence. The study recommends that gender equality should be promoted and violence against women should be discouraged in order to accelerate fertility transition in Malawi.
\end{abstract}

Keywords: Spousal violence, unwanted fertility, pregnancy, Malawi

' Corresponding author email: liasuayotunde@gmail.com 


\section{Résumé}

L'identification des facteurs prédictifs de fertilité élevée au Malawi a toujours été une grande inquiétude parmi des dépositaires. Un secteur qui n'a pas suscité beaucoup d'attention est le rapport entre la violence conjugale et la fertilité non désirée. Par conséquent, l'objectif de cet article a été d'établir le rapport entre la violence conjugale (physique, émotif et sexuel) et la fertilité non désirée parmi des femmes au Malawi. Un sous-ensemble de 4.137 femmes qui ont été choisies pour le module domestique de violence et qui ont donné naissance dans les cinq dernières années ont été extraits à partir des donnees obtenues au bureau de Malawi 2010 Malawi Demographic and Health Survey. Des analyses logistiques Bivariantes et multi variables de régression ont été employées pour examiner le rapport entre la fertilité et les variables non désirées de fond. Le taux global de prédominance de violence conjugale et la fertilité non désirée parmi la population d'étude sont $31 \%$ et $46 \%$ respectivement. La violence conjugale s'est avérée un facteur prédictif significatif de fertilité non désirée parmi des femmes au Malawi. Les résultats des modèles logistiques bivariante et multi variables de régression indiquent que la fertilité non désirée est plus haute parmi les femmes qui ont éprouvé la violence conjugale que parmi ceux qui pas $(O R=0.765)$. D'autres facteurs qui se sont avérés être sensiblement liés à la fertilité non désirée sont naissance d'âge au début, nombre d'enfants jamais nés, accord conjugale sur le nombre idéal de l'index de richesse de ménage d'enfants et région de résidence. L'étude recommande que l'égalité de genre devrait être favorisée et la violence contre des femmes devrait être découragée accélèrent la transition de fertilité au Malawi.

Mots-clés: violence conjugale, les grossesses non désirées, la grossesse, le Malawi

\section{Introduction}

Gender-based violence (GBV) is defined as violence directed at an individual based on his or her biological sex, gender identity, or perceived adherence to socially defined norms of masculinity and femininity (USAID, 20I2). GBV is a common practice that has been with humankind in most societies of the world from time immemorial. It may be psychological or mental which is also variously known as domestic violence (Odimegwu, Okemgbo \& Ayila, 2010). Gender-based violence has been a neglected public health issue until recently that much concern are been given in public health discourse (Kishor \& Johnson, 2004).Apart from the economic, social, psychological and human right implications of this type of violence, GBV is associated with adverse reproductive health, general poor health outcome and many other negative consequences on the wellbeing of the victims who are mostly women and girls (Kishor \& Johnson, 2004; Bibi, Ashfaq, Shaikh \& Qureshi, 20I4; Solanke, 20I4; Wekwete, Sanhokwe, Murenjekwa, Takavarasha \& Madzingira, 20I4). Reports across the globe (Himanshu 
\& Panda, 2007; De Wet, 2009; Antai, 20II; Okemiri \& Adekola, 20I2) have suggested negative influence of gender-based violence on women's reproductive health.

Gender-based violence which has no social or cultural barrier as it cut across all human strata (Heise, Pitanguy \& Germain, 1995; WHO, 2005) has been on without much attention, but has now become a global issue(Bamiwuye \& Odimegwu, 2014). Though with different estimates, approaches and patterns many studies have reported that up to $70 \%$ of all women worldwide had experienced one form of violence or the other at one time of their lives (Heise, Ellsberg \& Guttemoeller, 1999; Oyediran \& Isiugo-Abanihe, 2005; Garcia-Moreno, Jansen, Ellsberg, Heise \& Watts, 2006) and appreciable number of this violence are perpetrated by their spouses or intimate partners (Hindin, Kishor \& Ansara, 2008; NSO/ICF Macro, 20II). It was particularly reported by Hindin and his collaborations in 2008 that perpetration of violence by current husband or partner ranges from 75 per cent in Bangladesh to 16 per cent in the Dominican Republic (Hindin, Kishor \& Ansara, 2008).

Severally, within the last two decades that the issue of violence against women came to the international discourse, reports of this type of violence most especially by their intimate partners have been worrisome in all regions of the world from less developing nations to the developed countries. Using ownership of property as a yardstick, Kes (2008) conducted a survey in Kerela, India and reported as high as $49 \%$ of women without property ever experienced violence. According to Galindo \& Serrano,
(1994) (see Agnihotri, Agnihotri, Jeebun \& Purwar, 2006) in Spain women were often the victims of violence and of domestic violence where 86 violent deaths and 200,000 cases of abuse by partners were recorded in 1993. Studies have also revealed high rate of domestic violence against women in United Kingdom (McGibbon, Cooper \& Kelly, 1989; Stanko, Crisp, Hale \& Lucraft, 1997; MirrleesBlack, 1999).

GBV against women in general and pregnant women in particular is a neglected area of research worldwide, particularly in Malawi (Chasweka, Chimwaza, Maluwa \& Odland, 20I2). This is not being fair considering the high prevalence of gender-based domestic violence (GBDV) in the country. The 2010 Malawi Demographic and Health Survey (MDHS) reported that close to $30 \%$ of all women, pregnant women inclusive suffer GBDV. Whenever any study mentions GBDV, the negative reproductive outcome is mentioned, while those many pregnancies and childbirths as a consequence of coercion (physical, sexual and/or emotional violence) from the spouses go unmentioned. Search for significant predictors of high fertility in Malawi has been on for decades without satisfactory, appreciable or appropriate solution in sight, despite the success story of high contraceptive prevalence rate in the country amidst other nations in African continent (Chasweka, Chimwaza, Maluwa \& Odland, 20I2).

Fertility in Malawi remains high although there is some evidence of a decline. For instance, available statistical data show that the total fertility rate (TFR) in the country has fallen significantly. 
Specifically, it has fallen by 2.0 between 1977 and 2010.(Malawi Government, 1984, 1994a, 1994b, 2002, 2006, 201 I). However, reasons for the decline still remained inexplicable and incomprehensible, and again there is yet no explanation for the mismatch between the observed fertility levels and Contraceptive Prevalence Rate (CPR) in the country. The CPR for modern methods of contraception has increased in Malawi from less than $1 \%$ in 1984 to $7 \%, 12 \%, 21 \%$ and $22 \%$ in 1992, 1996, 2000 and 2004, respectively (Malawi Government, 1987, 1994b, 1997, 2002, 2006). The remarkable increase in contraceptive use and sluggish decline in fertility has resulted into an increase in studies focusing on fertility and contraceptive use in Malawi (see for example, Chintsanya 2013; Chintsanya, Madise \& Bailey, 2013). Recently, some researchers have demonstrated that gender-based violence is another important determinant of fertility in Africa (Odimegwu, Bamiwuye \& Adedini, 2015). It was added by Campbell (2002) that among the many health consequences of violence against women was miscarriages, abortions, unwanted pregnancy and low birth weight. Hence the objectives of this present study.

Mainly, the present study examines the relationship between experience of spousal violence and unwanted childbirth in Malawi and specifically examines the socio-economic and demographic variables relating to the incidence of unwanted childbirth in the country.

\section{Methodology}

\section{Data}

The study used secondary data extracted from the most recent and credible 2010 Malawi Demographic Health Survey (MDHS) conducted by the National Statistical Office with financial and technical assistance from ICF Macro (Malawi Government 201I). The survey was the fourth Demographic and Health Survey (DHS) ever conducted in Malawi and involved a multi-stage probability sampling to select 23,020 women of reproductive age. Survey procedure and instruments were ethically approved by the Ethics Committee of the ICF Macro International, Inc., Calverton, Maryland, USA and the National Ethics Committee of Malawi. Detailed report of the methodologies involved in data collection can be obtained from the appropriate survey report (Malawi Government, 20II). However, the current research work is predicated on the examination of weighted sub-sample. The sub-sample was selected on two levels approach. Firstly, those respondents that were interviewed for domestic violence module were first kept and secondly, those respondents who ever had a birth were equally kept for the analysis. The specific constructed weight used for domestic violence module in Measure Demographic Health Survey data was applied and this now gave us a total size of $4,137(18 \%$ of the total respondents) women who gave birth within the last 5 years and those that were included in domestic violence module. 


\section{Methods of Analysis}

This research work employed multidimensional techniques of data analysis vis-à-vis descriptive/univariate; bivariate; and binary logistic regression analytical techniques/methods. These were utilized to show the frequency distribution of the research variables; determine relationships between variables; and to explore relationship between violence among couple and unwanted fertility and also to investigate the net effect of socio-economic and demographic issues on unwanted fertility in the country under study. The dichotomous nature of the dependent variable informed the use of the latter technique. .A four models binary logistic regression was applied in the multivariate analysis to be able to see the net effect of individual and group independent variables on the dependent variable. While the first model examine the association between the dependent and the main independent variables, the second and third observed the relationship while controlling for the demographic and socioeconomic variables respectively and the last (model 4) examine the relationship combining all the variables.

\section{Description of variables \\ Dependent/Outcome variable}

The dependent/outcome variable for the study is unwanted fertility. The dependent variable "unwanted fertility" was conceptualized as follows; women who had ever given birth within the last five years were asked if the last birth was wanted, wanted later or wanted no more. If wanted 0 was allocated and $I$ if wanted later or wanted no more. The aggregate of the two categories (wanted later and wanted no more) gave us the total number of women who had ever experienced unwanted fertility.

\section{Independent variable}

The main independent variable describes women who have experienced spousal violence. The study is looking at GBDV committed by husband or partner, hence the use of the phrase spousal violence. Spousal violence was conceptualized in the study in such a way that it captured the three dimensions of violence: physical, sexual and emotional. This variable was constructed by combining a series of questions that were asked to determine whether or not the respondents experienced physical, sexual and or emotional violence by the spouse. The variable "physical violence" was determined from the response to questions asking whether the respondent had experienced at least one of the six subtypes of physical violence: whether or not either of the partner ever pushed, shook or threw something; ever slapped; ever punched; spouse ever attempted to strangle or burn; spouse ever attacked with knife, gun or other weapon. The emotional violence variable comprised three variables: either of the partner ever threatened with harm; either of the partner ever humiliated and spouse ever insulted or made to feel bad. Emotional violence variable was obtained by summing the three items. The sexual violence comprised of three variables: ever sexual violence, ever physically forced sex and ever forced to perform sexual acts. Each item was given a score of $I$ if she experienced abuse and 0 if she did not 
experience abuse. Summation of all items for each individual was obtained. If the total score was " 0 " the individual was categorized not to have experienced spousal violence otherwise any score different from " 0 " meant that the individual had experienced spousal violence.

Control variables used in this study were age, educational attainment, wealth index, place of residence, region of residence, marital status, religion, family type, age at first birth, partner's educational level, children ever born and agreement in number of children wanted by both spouses were selected as the intervening variables. While many of these variables have been found to have a significant relationship with fertility in a number of studies (Odimegwu et. al., 2015), some were selected due to the envisaged relationship to unwanted fertility.

The various sections of the women questionnaire contain all the independent variables. The categorizations of the selected variables were recorded as follows Age (I5-24, 25-29, 30-34, 35-39, 40-44 and 45-49); Educational attainment (No education, Primary, Secondary and Higher); Place of residence (Urban and Rural), Region (Northern, Central and Southern), Family type (Monogamy and Polygamy); Wealth (Poor, Middle and Rich), Marital status (Never married, Married, Widowed and Divorced/Not living together), Religion (Christian, Muslim and Traditional/Others), Age at first birth ( 19 or less and 20 or more), Children ever born ( 4 or less and 5 or more). Others are Partners' educational attainment (No education, Primary, Secondary and Higher); Spousal agreement on number of children wanted (Both want same, Husband wants more, Husband want fewer and Never discuss it).

\section{Results}

Socio-economics and demographic characteristics of respondents

Respondents were relatively young with a mean age of 28 years of which majority were in the youngest reproductive category (15-29 years) and lowest frequency in the category of 45-49 age group . Educational status of women was limited with no less than $85 \%$ having no formal or primary educational level and about $15 \%$ having secondary or higher education. Table I further indicates that the majority of the three sub-groups of wealth index among the study population (43\%) were poor and less than four in every ten respondents were in the rich category of the wealth index. While $85 \%$ of the respondents were rural dwellers, $46 \%$ were from Southern region while $44 \%$ sampled women were from Central of Malawi and the remaining $11 \%$ were from the Northern part of the country. In terms of religion, eight in every ten were Christian, $15 \%$ and $1 \%$ were Muslim and Traditional faith believers respectively. Evidence from the data as presented in Table I reveals a high rate of early childbirth in Malawi with (7I\% having their first child birth before 20 years of age). Partner's educational attainment showed that $71 \%$ of the respondents had partners with less than secondary education while just two per cent had higher education. Majority (70\%) of the sampled respondents reported having 4 or less children as at the time of the survey though 
most of them (respondents) were still in their prime years of reproduction. Onewife and one-husband (monogamous) type of family reigns than multiple wives to a single man system in Malawi. Spousal agreement on number of wanted children was another variable examined in the study and as presented in Table I it was shown that while $56 \%$ of the respondent wanted the same number of children as did their partners, $20 \%$ reported never discussed such theme with partners and 15\% claimed that husband wanted more children than they wanted. Table I also presents the prevalence of spousal violence and unwanted fertility as $31 \%$ and $46 \%$ respectively.

Table I. Percentage Distribution of Selected Background Characteristics of Women who gave birth within the Last 5yearsand who were interviewed for domestic violence module in Malawi, 2010

\begin{tabular}{|l|r|r|}
\hline Variables/Categories & Frequency & Percentage \\
\hline Age (years) & 269 & 6.5 \\
\hline $15-19$ & 1105 & 26.7 \\
\hline $20-24$ & 1266 & 30.6 \\
\hline $25-29$ & 711 & 17.2 \\
\hline $30-34$ & 489 & 11.8 \\
\hline $35-39$ & 203 & 4.9 \\
\hline $40-44$ & 93 & 2.3 \\
\hline $45-49$ & 28.2 & \\
\hline Mean age of respondents & & 15.2 \\
\hline Place of residence & 629 & 84.8 \\
\hline Urban & 3508 & 10.6 \\
\hline Rural & & 43.6 \\
\hline Region of Residence & 440 & 45.8 \\
\hline Northern Region & 1802 & \\
\hline Central Region & 1894 & 70.6 \\
\hline Southern Region & & 29.4 \\
\hline Age at first birth (years) & 2921 & \\
\hline 19 or less & 1215 & 69.7 \\
\hline 20 or more & & 30.3 \\
\hline No. of Children ever born & 2884 & \\
\hline 4 or less & 1253 & 55.6 \\
\hline 5 or more & & 15.1 \\
\hline Spousal agreement of CEB ++ & 1895 & 9.6 \\
\hline Both want same & 515 & 19.6 \\
\hline Husband wants more & 327 & 16.8 \\
\hline Husband wants fewer & 669 & 67.8 \\
\hline Never talk about it & & \\
\hline Educational level & 2803 & \\
\hline No Education & & \\
\hline Primary & & \\
\hline
\end{tabular}


African Population Studies Vol. 29, No. 2, Supplement, 2015

\begin{tabular}{|c|c|c|}
\hline Variables/Categories & Frequency & Percentage \\
\hline Secondary & 609 & 14.7 \\
\hline Higher & 30 & 0.7 \\
\hline \multicolumn{3}{|l|}{ Wealth Index } \\
\hline Poor & 1773 & 42.9 \\
\hline Middle & 884 & 21.4 \\
\hline Rich & 1480 & 35.8 \\
\hline \multicolumn{3}{|l|}{ Partner's education level ++} \\
\hline No Education & 416 & 10.3 \\
\hline Primary & 2463 & 61.0 \\
\hline Secondary & 1078 & 26.7 \\
\hline Higher & 80 & 2.0 \\
\hline \multicolumn{3}{|l|}{ Marital Status } \\
\hline Never married & 61 & 1.5 \\
\hline Married/living together & 3611 & 87.3 \\
\hline Widowed & 75 & 1.8 \\
\hline Divorced/Not living together & 389 & 9.4 \\
\hline \multicolumn{3}{|l|}{ Religion } \\
\hline Christianity & 3469 & 84.0 \\
\hline Muslim & 617 & 14.9 \\
\hline Traditional/Others & 46 & 1.1 \\
\hline \multicolumn{3}{|l|}{ Type of family ++} \\
\hline Monogamy & 3106 & 88.4 \\
\hline Polygamy & 491 & 13.6 \\
\hline \multicolumn{3}{|c|}{ Experience of Spousal Violence ++} \\
\hline Never experienced & 2805 & 69.3 \\
\hline Ever experienced & 1245 & 30.7 \\
\hline \multicolumn{3}{|c|}{ Experience of unwanted fertility ++} \\
\hline Never experienced & 2247 & 54.4 \\
\hline Ever experienced & 1887 & 45.6 \\
\hline
\end{tabular}

++ Absolute Number less than the total 4, 137 due to missing system but valid per cent was reported throughout in the analysis

Relationship between unwanted fertility and background characteristics of women in Malawi

Bivariate analyses were conducted to study the relationship between unwanted fertility and selected socio-economic and demographic background variables of respondents. Table 2 shows the number and percentage distributions of women who had unwanted fertility by some selected background characteristics. A significant association exists between occurrence of unwanted fertility and age, region, amount of unborn children, spousal agreement on amount of ideal children, marital status, type of family and experience of spousal violence. Older women, who had more than five children, never married or divorced, from polygamous family setting have a very high propensity to experience unwanted fertility compare to other group or category of women. Furthermore, mothers who ever experienced spousal 
violence and who reside in central or more than their other counterparts southern regions were also likely to $(p<0.001)$.

experience unwanted or mistimed fertility

Table 2 Per cent Distribution of women who ever had unwanted childbirth by selected background characteristics

\begin{tabular}{|c|c|c|c|c|c|}
\hline \multirow{2}{*}{\multicolumn{2}{|c|}{ Variables/Characteristics }} & \multicolumn{4}{|c|}{ Ever had Unwanted Childbirth } \\
\hline & & \multirow{2}{*}{$\begin{array}{r}\% \\
35.7\end{array}$} & \multirow{2}{*}{$\frac{N}{96}$} & \multirow{2}{*}{$\begin{array}{r}\text { Total } \\
269\end{array}$} & \multirow{2}{*}{$\begin{array}{c}\begin{array}{c}\text { Chi-Square } \\
\text { (p-value) }\end{array} \\
82.403\end{array}$} \\
\hline \multirow[t]{7}{*}{ Age (years) } & $15-19$ & & & & \\
\hline & $20-24$ & 40.3 & 445 & 1103 & \multirow[t]{6}{*}{$(0.000)$} \\
\hline & $25-29$ & 44.1 & 558 & 1266 & \\
\hline & $30-34$ & 45.9 & 326 & 711 & \\
\hline & $35-39$ & 56.1 & 274 & 488 & \\
\hline & $40-44$ & 63.9 & 129 & 202 & \\
\hline & $45-49$ & 61.3 & 57 & 93 & \\
\hline \multirow[t]{2}{*}{ Place of residence } & Urban & 46.3 & 291 & 629 & \multirow{2}{*}{$\begin{array}{l}0.110 \\
(0.740)\end{array}$} \\
\hline & Rural & 45.5 & 1596 & 3504 & \\
\hline \multirow[t]{3}{*}{ Region of Residence } & Northern Region & 33.0 & 145 & 440 & \multirow{3}{*}{$\begin{array}{l}33.142 \\
(0.000)\end{array}$} \\
\hline & Central Region & 46.3 & 834 & 1802 & \\
\hline & Southern Region & 48.0 & 908 & 1891 & \\
\hline \multirow[t]{2}{*}{ Age at first birth (years) } & 19 or less & 46.0 & 1343 & 2920 & \multirow{2}{*}{$\begin{array}{l}0.483 \\
(0.254)\end{array}$} \\
\hline & 20 or more & 44.8 & 544 & 1214 & \\
\hline \multirow[t]{2}{*}{ No. of Children ever born } & 4 or less & 40.2 & 1160 & 2882 & \multirow{2}{*}{$\begin{array}{l}112.196 \\
(0.000)\end{array}$} \\
\hline & 5 or more & 58.1 & 727 & $|25|$ & \\
\hline \multirow[t]{4}{*}{ Spousal agreement of CEB } & Both want same & 39.9 & 757 & 1895 & \multirow{4}{*}{$\begin{array}{l}26.492 \\
(0.000)\end{array}$} \\
\hline & $\begin{array}{l}\text { Husband wants } \\
\text { more }\end{array}$ & 48.1 & 247 & 514 & \\
\hline & $\begin{array}{l}\text { Husband wants } \\
\text { fewer }\end{array}$ & 53.2 & 174 & 327 & \\
\hline & Never talk about it & 43.5 & 291 & 669 & \\
\hline \multirow[t]{4}{*}{ Educational level } & No Education & 49.4 & 343 & 694 & \multirow{4}{*}{$\begin{array}{l}5.090 \\
(0.165)\end{array}$} \\
\hline & Primary & 44.9 & 1258 & 2801 & \\
\hline & Secondary & 45.0 & 274 & 609 & \\
\hline & Higher & 40.0 & 12 & 30 & \\
\hline \multirow[t]{3}{*}{ Wealth Index } & Poor & 45.6 & 808 & 1772 & \multirow{3}{*}{$\begin{array}{l}0.932 \\
(0.628)\end{array}$} \\
\hline & Middle & 46.9 & $4 \mid 4$ & 882 & \\
\hline & Rich & 44.9 & 664 & 1479 & \\
\hline \multirow[t]{2}{*}{ Partner's education level } & No Education & 48.3 & 201 & 416 & \multirow{2}{*}{$\begin{array}{l}4.249 \\
(0.236)\end{array}$} \\
\hline & Primary & 45.6 & 1122 & 2461 & \\
\hline
\end{tabular}




\begin{tabular}{|c|c|c|c|c|c|}
\hline \multirow[b]{2}{*}{ Variables/Characteristics } & & \multicolumn{4}{|c|}{ Ever had Unwanted Childbirth } \\
\hline & & \% & $M$ & T & Chi-Square \\
\hline & Secondary & 42.8 & 462 & 1079 & \\
\hline & Higher & 45.0 & 36 & 80 & \\
\hline \multirow[t]{4}{*}{ Marital Status } & Never married & 70.5 & 43 & 61 & \multirow{4}{*}{$\begin{array}{l}32.674 \\
(0.000)\end{array}$} \\
\hline & $\begin{array}{l}\text { Married/living } \\
\text { together }\end{array}$ & 44.1 & 1593 & 3610 & \\
\hline & Widowed & 56.0 & 42 & 75 & \\
\hline & $\begin{array}{l}\text { Divorced/Not } \\
\text { living together }\end{array}$ & 54.0 & 210 & 389 & \\
\hline \multirow[t]{3}{*}{ Religion } & Christianity & 45.5 & 1576 & 3466 & \multirow{3}{*}{$\begin{array}{l}1.445 \\
(0.485)\end{array}$} \\
\hline & Muslim & 45.7 & 282 & 617 & \\
\hline & Traditional/Others & 54.3 & 25 & 46 & \\
\hline \multirow[t]{2}{*}{ Type of family } & Monogamy & 43.5 & 1352 & 3105 & \multirow{2}{*}{$\begin{array}{l}3.516 \\
(0.034)\end{array}$} \\
\hline & Polygamy & 48.1 & 236 & 491 & \\
\hline \multirow{2}{*}{$\begin{array}{l}\text { Experience of Spousal } \\
\text { Violence }\end{array}$} & Never experienced & 43.1 & 1209 & 2802 & \multirow{2}{*}{$\begin{array}{l}15.397 \\
(0.000)\end{array}$} \\
\hline & Ever experienced & 49.8 & 620 & 1245 & \\
\hline
\end{tabular}

Determinants of unwanted fertility: Multivariate analysis

In order to determine the relationship between unwanted fertility and spousal violence a four model binary logistic regression was conducted. The results of this exercise are given in Table 3.In the first model, the unadjusted odds of unwanted fertility was significantly higher among women who had ever experienced spousal violence than those other women who never experienced spousal violence. It was discovered that women who never experienced spousal violence were significantly 0.77 less likely to experience unwanted fertility than those who ever experienced spousal violence. In model 2 , the inclusion of some selected demographic background characteristics of respondents, which serve as the control variables did not have a pronounced impact on the interactions of experience of spousal violence and the likelihood of unwanted fertility among the respondents. The odds ratio of unwanted fertility remained almost the same when no control variable was introduced in model I. Of all the demographic variables tested in this second model, only region, number of children ever born and spousal agreement on ideal number of children had significant effects on the relationship between spousal violence and the occurrence of unwanted fertility.

The third model shows the interaction between spousal violence and unwanted fertility while controlling for the socioeconomic background characteristics. But unfortunately while performing the third and fourth models marital status variable was dropped by SPSS. The odds ratio of unwanted fertility was significantly still higher among women who experienced spousal violence than those women who 
never experienced spousal violence. It was revealed that women who never experienced spousal violence were significantly 0.79 less likely to experience unwanted fertility than those who ever experienced spousal violence. Surprisingly, none of the controlling socio-economic variables had a significant co-founding effect on the relationship. Model 4 controlled for the net effect of both the demographic and socio-economic variables all together. While the incidence of unwanted fertility was still significantly higher among women who had experienced spousal violence, only region, age at first birth, number of children ever born, spousal agreement on ideal number of children and household wealth index indicated significant effect in the relationship.

Table 3Odds of ever-experience unwanted fertility by spousal violence experience and selected background characteristics of respondents.

\begin{tabular}{|c|c|c|c|c|}
\hline Variables & Model I & Model 2 & Model 3 & Model 4 \\
\hline \multicolumn{5}{|c|}{ Main independent variable } \\
\hline \multicolumn{5}{|c|}{ Experience of Spousal Violence } \\
\hline Never experienced & $0.765 * * *$ & $0.766 * * *$ & $0.790 * * *$ & $0.785 * * *$ \\
\hline Ever experienced ${ }^{\mathrm{RC}}$ & 1.000 & 1.000 & 1.000 & 1.000 \\
\hline \multicolumn{5}{|c|}{ Demographic Variables } \\
\hline \multicolumn{5}{|c|}{ Age (years) } \\
\hline $15-19$ & & 0.596 & & 0.556 \\
\hline $20-24$ & & 0.968 & & 0.896 \\
\hline $25-29$ & & 1.025 & & 0.936 \\
\hline $30-34$ & & 0.797 & & 0.737 \\
\hline $35-39$ & & 1.040 & & 1.031 \\
\hline $40-44$ & & 1.728 & & 1.691 \\
\hline $45-49^{\mathrm{RC}}$ & & 1.000 & & 1.000 \\
\hline \multicolumn{5}{|l|}{ Place of residence } \\
\hline Urban & & 1.130 & & 1.246 \\
\hline Rural ${ }^{R C}$ & & 1.000 & & 1.000 \\
\hline \multicolumn{5}{|l|}{ Region of Residence } \\
\hline Northern Region & & $0.480 * * *$ & & $0.437 * * *$ \\
\hline Central Region & & 0.969 & & 0.916 \\
\hline SouthernRegion ${ }^{R C}$ & & 1.000 & & 1.000 \\
\hline \multicolumn{5}{|c|}{ Age at first birth (years) } \\
\hline 19 or less & & 1.143 & & $1.197 *$ \\
\hline 20 or more $\mathrm{r}^{\mathrm{RC}}$ & & 1.000 & & 1.000 \\
\hline \multicolumn{5}{|c|}{ No. of Children ever born } \\
\hline 4 or less & & $0.494 * * *$ & & $0.473 * * *$ \\
\hline 5 or more ${ }^{R C}$ & & 1.000 & & 1.000 \\
\hline
\end{tabular}


African Population Studies Vol. 29, No. 2, Supplement, 2015

\begin{tabular}{|c|c|c|c|c|}
\hline Variables & Model I & Model 2 & Model 3 & Model 4 \\
\hline \multicolumn{5}{|c|}{ Main independent variable } \\
\hline \multicolumn{5}{|c|}{ Spousal agreement of CEB } \\
\hline Both want same & & 0.984 & & 0.951 \\
\hline Husband wants more & & 1.148 & & 1.141 \\
\hline Husband wants fewer & & $1.562 * * *$ & & $1.593 * * *$ \\
\hline Never talk about it ${ }^{R C}$ & & 1.000 & & 1.000 \\
\hline \multicolumn{5}{|c|}{ Socioeconomic variables } \\
\hline \multicolumn{5}{|c|}{ Educational level } \\
\hline No Education & & & 1.395 & 1.203 \\
\hline Primary & & & $\mathrm{I} .144$ & 1.325 \\
\hline Secondary & & & 1.133 & 1.599 \\
\hline Higher $^{\mathrm{RC}}$ & & & 1.000 & 1.000 \\
\hline \multicolumn{5}{|l|}{ Wealth Index } \\
\hline Poor & & & 1.008 & $1.307 * *$ \\
\hline Middle & & & 1.047 & $1.356 * *$ \\
\hline Rich RC & & & 1.000 & 1.000 \\
\hline \multicolumn{5}{|c|}{ Partner's education level } \\
\hline No Education & & & 0.969 & 0.616 \\
\hline Primary & & & 0.943 & 0.700 \\
\hline Secondary & & & 0.835 & 0.288 \\
\hline Higher ${ }^{\mathrm{RC}}$ & & & 1.000 & 1.000 \\
\hline \multicolumn{5}{|l|}{ Religion } \\
\hline Christianity & & & 0.727 & 0.785 \\
\hline Muslim & & & 0.642 & 0.642 \\
\hline Traditional/Others ${ }^{\mathrm{RC}}$ & & & 1.000 & 1.000 \\
\hline \multicolumn{5}{|l|}{ Type of family } \\
\hline Monogamy & & & 0.872 & 0.885 \\
\hline PolygamyRC & & & 1.000 & 1.000 \\
\hline -2 Log Likelihood & 5558.607 & 4429.140 & 4341.054 & 4350.598 \\
\hline Chi-Square & 15.436 & 195.316 & 25.131 & 219.394 \\
\hline Sig. & 0.000 & 0.000 & 0.014 & 0.000 \\
\hline
\end{tabular}

*significant at $P<0.001$

\section{Discussion}

Violence in every corner of the family unit and within the four walls of the place of abode is a common, but hidden phenomenon everywhere world over. While many go unreported, many that were reported went away without appropriate or commensurate punishment for the offenders. Women and girl child, the so called "weaker vessels" were most often than not always at the receiving end of many of the domestic violence. Despite 
the fact that most communities and societies frown at violence against women, the reality is that violations against women's human rights are often sanctioned under the garb of cultural practices and norms, or through misinterpretation of religious tenets (UNICEF, 2000). Unfortunately, appreciable number of the domestic violence are perpetrated by women's husbands or close partners (spousal violence) (Hindin, Kishor \& Ansara, 2008; Malawi Government, 20I I; Bibi, Ashfaq, Shaikh \& Qureshi, 20I4), this makes proper prosecution difficult most times. Maybe if appropriate punishment has been meted out against the abusers to serve as deterrent to others, the high rate of spousal violence could have been reduced. Considering the socio-economic, demographic, health and psychological negative implications of spousal violence one would know that much is still desired to be done in bringing the menace to its knee. Malawi, despite her success story on the uptake of contraceptive among all other Africa countries has been on the search for the significant predictors of the high fertility rate for the country. One area that has not been explored is the unwanted pregnancies and childbirth that were likely to be as a result of coerciveness (physical and emotional) and forceful sexual act from the spouses.

Using 4, I 37 sampled women who gave birth within the last five years to the survey and who were selected for domestic violence module in 2010 Malawi Demographic and Health Survey, our study found a prevalence rate of $30.7 \%$ ever experienced spousal violence in Malawi and this is in consonant with other nationally reported figure of between $15 \%$ and $71 \%$ in some other countries (GarciaMoreno, Jansen, Ellsberg, Heise \& Watts, 2005; Hindin, Kishor \& Ansara, 2008; Bibi, Ashfaq, Shaikh \& Qureshi, 20 I4; Bamiwuye \& Odimegwu, 2014; Wekwete, Sanhokwe, Murenjekwa, Takavarasha \& Madzingira, 2014). On the basis of unwanted fertility, our study found a $46 \%$ prevalence rate among these sub-sampled women in Malawi. This is almost at par with the national rate of unwanted pregnancies and mistimed of the last birth and pregnancies put together in the country (Malawi Government, 20II).The prevalence of unwanted fertility among ever married women in Malawi is similar to that found in other countries like Cambodia, Colombia, the Dominican Republic, Egypt, India, Nicaragua, and Peru studies where a higher proportion of women who had experienced spousal violence also reported having unwanted fertility than those who never experienced violence (Kishor \& Johnson, 2004).

Findings from the multivariate analysis across all the four models revealed a significantly higher prevalence of unwanted fertility among women who had experienced spousal violence than those who never experienced spousal violence. Women, who reside in northern region, who had 4 or less children and who had first birth at 20 years or more were significantly less likely to have unwanted fertility than the occurrence among their other counterparts. Those ones who were poor and in the middle class of wealth index and whose partners want fewer children were significantly more likely to have unwanted fertility than their other counterparts respectively. 
Difference in ideal number of children between spouses might be one of the factors responsible for this spousal's misunderstanding and violence. When women or partners considered they have enough or need more children, but either of the spouses could agree with the decision or consideration, then this disagreement could erupt into violence. And again, this result might not be so surprising because the multivariate analysis further showed a higher likelihood of spousal violence and occurrence of unwanted childbirths among women who were also of low or no formal educational attainment, women who were from poor or middle class and women from Southern part of Malawi. The chances are high that these set of women were less empowered and have no say either in the reproductive health matters or even in the general decision of the house. The extent of unintended and unwanted fertility due to spousal violence shows the low status of women's reproductive rights, and the low degree of women's autonomy in Malawi. This is in tandem with UNICEF submission (UNICEF, 2000). This finding again could in a way collaborating the final report of 2010 Malawi Demography and Health Survey which stated that women from Southern part of Malawi were found to be of the lowest educational level and have the highest proportion of persons in the lowest wealth quintile for the country. It is paramount to identify these predictors of unwanted fertility, to enable policymakers and program planners channel efforts specifically to the women who are most likely to experience this problem.

In conclusion, the prevalence of unwanted fertility among ever married women in Malawi is very high and is closely and significantly related to spousal violence in the country. Our study has an important implication for policy, programme and strategy aiming at reducing fertility in this part of the world. Thus, there is need for women empowerment such that violence from their spouses could be reduced among them.

\section{Acknowledgements}

The authors gratefully acknowledge the National Statistical Office (NSO) and ICF Macro International [Calverton, Maryland, USA] for making the data available for public use. The authors wish to state that views expressed in this article are solely those of the authors, and not of National Statistical Office or ICF Macro International.

\section{References}

Antai, D. 20II. Controlling behavior, power relations within intimate relationships and intimate partner physical and sexual violence against women in Nigeria. BMC Public Health, II:5II. doi:I0.II86/I47I2458-II-

5 I I http://www.biomedcentral.com/ / 4 7|-2458/I I/5 II.pdf.

Agnihotri, A.K., Agnihotri, M., Jeebun, N. \& Purwar, B. (2006). Domestic Violence against women - an international concern. Clinic Knowledge Torture 16(I): 30-40.

Bamiwuye, S.O. \& Odimegwu, C. 2014. Spousal Violence in Sub-Saharan Africa: Does Household Poverty-Wealth Matter? Reproductive Health. I I (45): I-I0. doi:I0.I |86/I742-4755-II- 
45http://www.reproductive-healthjournal.com/content/ I I/I/45.

Bibi, S., Ashfaq, S., Shaikh, F. \& Qureshi, P.M.A. 20I4. Prevalence, Instigating Factors and Help Seeking Behavior of Physical Domestic Violence among Married Women of Hyderabad, Sindh. Pakistan Journal of Medical Sciences. 30(I): 122-

|25.doi:http://dx.doi.org//0.12669/pjm s.30I. 4533

http://www.pjms.com.pk/index.php/pi ms/article/view/4533

Campbell, J.C. 2002. Health consequences of intimate partner violence. Lancet 359: | $33|-| 336$.

Chasweka, R., Chimwaza, A., Maluwa, A. \& Odland, J.O. 20I2. Magnitude of Domestic Violence Against Pregnant Women in Malawi. Journal of Research in Nursing and Midwifery. I(2): I7-2I.

Chintsanya, J. 2013. Trends and Correlates of Contraceptive Use among Married Women in Malawi: Evidence from 2000-2010 Malawi Demographic and Health Surveys. DHW Working Paper No. 87, ICF International. Calverton, Maryland, USA.

Chintsanya, J.M.N., Madise, N.J. \& Bailey, C.E. 20/3. Fertility dynamics and contraceptive use in Malawi paper presented at the International Population Conference, IUSSP, August 26-30 August, 2013.

De Wet, N. 2009. Domestic violence and child health outcomes in Zimbabwe. University of the Witwatersrand. PhD Dissertation.

Galindo, E. \& Serrano, N. 1994. Spain. Women in the world. Womens' Health Newsletter. August 23:8.
García-Moreno, C., Jansen, H.A., Ellsberg, M., Heise, L. \& Watts, C.H. 2005. WHO Multi-country Study on Women's Health and Domestic Violence against Women Initial results on prevalence, health outcomes and women's responses. WHO Press: Switzerland.

García-Moreno, C., Jansen, H.A., Ellsberg, M., Heise, L. \& Watts, C.H. 2006. Prevalence of intimate partner violence: findings from the WHO multi-country study on women's health and domestic violence. Lancet 2006, 368(9543): |260-| 269.

Heise, L., Pitanguy, L.J. \& Germain, A. 1995. Violence Against Women: the Hidden Health Burden. World Bank Discussion Paper, No. 255. Washington DC: World Bank.

Heise, L., Ellsberg, M. \& Guttemoeller, M. 1999. Ending violence against women. Population Report, Series L. I I: I-44.

Himanshu, S.R. \& Panda, K.P. 2007. Gender and development: Dimension and strategies, Introduction and Overview. MPRA, paper no 6559. New Century Publication, New Delhi.

Hindin, M.J., Kishor, S. \& Ansara, D.L. 2008. Intimate Partner Violence among Couples in 10 DHS Countries: Predictors and Health Outcomes. Demographic Health Survey Analytical Studies No. 18. Calverton: Macro International Inc.

Kes, A. 2008. Presentation of Millennium Project Gender Task Force Results: International Center for Research on Women and UN Millennium Project. Gender and Education Task Force.

Kishor, S. \& Johnson, K. 2004. Profiling Domestic Violence: A Multi-Country 
African Population Studies Vol. 29, No. 2, Supplement, 2015

Study. Calverton: MACRO International.

Malawi

Government,

1987. Malawi Demographic Survey

1982. Zomba: National Statistical Office.

Malawi

Government,

1994a. Malawi Population and Housing Census 1987: Analytical

Report (Volume VII), Zomba: National Statistical Office.

Malawi

Government,

1994b. Malawi Demographic and Health Survey 1992, Zomba: National Statistical Office and Macro International Inc.

Malawi

Government,

1997. Malawi Knowledge, Attitudes and

Practices in Health Survey 1996.

Zomba: National Statistical Office and Macro International Inc.

Malawi

Government.

2002. Malawi Demographic and Health Survey 2000, Zomba: National Statistical Office and Macro International Inc.

Malawi Government. 2006. Malawi Demographic and Health Survey 2004. Zomba: National Statistical Office and Macro International Inc.

Malawi Government. 20II. Malawi Demographic and Health Survey, 2010. Zomba, Malawi, and Calverton, Maryland, USA: NSO and ICF Macro.

McGibbon, A., Cooper, L. \& Kelly, L. 1989.

What support? Hammersmith and Fulham council community police committee domestic violence. London: Polytechnic of North London.

Mirrlees-Black, C. 1999. Domestic violence: finding from a new British crime survey self-completion questionnaire. London: Home Office.

Odimegwu, C., Okemgbo, C.N. \& Ayila, R. 2010. Dynamics of gender-based violence among the Tivs of North Central Nigeria. African Population Studies,24(3): 238-258.

Odimegwu, C., Bamiwuye, O.S. \& Adedini, S.A. 20I5. Gender-based violence as a new proximate determinant of fertility in sub-Saharan Africa. Southern African Journal of Demography, I6(I):87-I 22.

Okemiri, E.B. \& Adekola, G. 2012. Violence against women in lkwere Ethnic Nationality of Nigeria: Challenges for gender equity and development. Studies in Sociology of Science, 3(2):6-I 2.

Oyediran, K.A. \& Isiugo-Abanihe, U. 2005. Perceptions of Nigerian Women on Domestic Violence: Evidence from 2003 Nigerian Demographic and Health Survey. African Journal of Reproductive Health. 9(2): 38-53.

Solanke, B.L. 20I4. Association between intimate partner violence and utilisation of maternal health services in Nigeria. African Population Studies,28(2): 933945.

Stanko, E., Crisp, D., Hale, C. \& Lucraft, H. 1997. Counting the costs: estimating the impact of domestic violence in the London Borough of Hackney Safer Cities.

United Nations Children's Fund (UNICEF), 2000. Domestic Violence against Women and Girls. United Nations Children's Fund Innocenti Research Centre, Innocenti Digest 6. Florence, Italy, United Nations Children's Fund. 
United States Agency International Development (USAID).2012. Strategy to Prevent and Respond to GenderBased Violence Globally. United States Agency International Development. http:// pdf.usaid.gov/pdf_doc/PDACT888.pdf.

Wekwete, N.N., Sanhokwe, H., Murenjekwa, W., Takavarasha, F. \& Madzingira, N. 2014. The Association between Spousal Gender Based Violence and Women's Empowerment among Currently Married Women aged 15-49 in Zimbabwe: Evidence from the 2010-II Zimbabwe Demographic and Health Survey. African Population Studies, 28(3): |4|3-|43|.

World Health Organisation (WHO). 2005. Addressing Violence Against Women and Achieving the Millennium Development Goals. Geneva, World Health Organisation, Department Gender, Women and Health, Family and Community Health. 